\title{
THE OCCURENCE OF THE EURASIAN OTTER LUTRA LUTRA IN AQUATIC HABITATS OF DIFFERENT TROPHY IN WIGRY NATIONAL PARK
}

\author{
Faculty of Biology and Environmental Studies, Cardinal Stefan Wyszyński University in Warsaw, \\ Warszawa, Poland \\ ${ }^{1}$ Wigry National Park, Krzywe 82, Suwałki, Poland \\ ${ }^{2}$ Department of Genetics and Animal Breeding, Warsaw University of Life Sciences - SGGW, Poland
}

\begin{abstract}
The standard method was used for the first field survey of the Eurasian otter Lutra lutra distribution in all aquatic habitats in Wigry National Park (WNP) in northern Poland. Total of 59 study sites (48 on lakes, 8 on rivers and 3 on drainage ditches) were visited twice between 12th and18th of March and between 8th and 13th of May 2018. Signs of otters were found in $42(71.2 \%)$ sites located throughout the whole area of Wigry National Park. The percentage of positive sites reached $100 \%$ in mesotrophic and eutrophic lakes as well as in rivers and meliorated canals. No signs of otter presence were recorded in dystrophic lakes located in the centre of peat-bogs. This marked difference in otter occurrence can be explained in the terms of different food availability: high in mesotrophic and eutrophic habitats and low in dystrophic lakes.
\end{abstract}

Key words: nature monitoring, otter survey, Wigry National Park.

\section{INTRODUCTION}

After the decline of the European populations of the Eurasian otter Lutra lutra (Macdonald and Mason 1988, 1994; Mason 1989), the recolonization process was recently observed in several European countries including Poland (Kranz et al. 2001; Mason and Macdonald 2004; Romanowski 2006; Prigioni et al. 2007). Consecutive regional surveys carried out in central and eastern Poland in 1996-1998, 2003 and 2007 documented an increase in the percentage of otter occurrences in sites surveyed (Brzeziński et al 1996; Romanowski 2006; Romanowski et al 2013). Otters were especially common in the Lakelands in northern Poland, along the western and eastern country borders, and in Carpathian Mountains (SE Poland). So far, since the confirmation of the presence of otters in Wigry National Park during national otter survey in 1996-1998, no following regular surveys of the area were conducted. The only evidence of tracks or otters killed by traffic on roads in the area was collected in a casual manner. Therefore, the aim of this study is to examine the Eurasian otter occurrence in Wigry National Park in all aquatic habitats of different trophy.

Corresponding author: Beata Grzegrzółka, Department of Genetics and Animal Breeding, Warsaw University of Life Sciences - SGGW, Jana Ciszewskiego 8, 02-786 Warszawa, Poland, e-mail: beata_grzegrzolka@sggw 


\section{MATERIAL AND METHODS}

The study was undertaken in the Wigry National Park $\left(151 \mathrm{~km}^{2}\right)$ in north-eastern Poland. The area covers parts of the Masurian Lake District and Augustów Primeval Forest. The landscape, shaped by a glacier, is dominated by forests $\left(95 \mathrm{~km}^{2}\right)$ and aquatic habitats $\left(29 \mathrm{~km}^{2}\right)$, the remaining land is mostly agricultural. The aquatic network is well developed and includes 42 lakes of different size and trophy, including the largest lake Wigry, covering the area of $21.87 \mathrm{~km}^{2}$.

Data on otter distribution were collected by visiting a total of 59 study sites (48 on lakes, 8 on rivers and 3 on drainage ditches). Each study site was surveyed twice: between 12th and18th of March and between 8th and 13th of May 2018. The standard otter monitoring technique was used to provide compatible results (Romanowski et al. 1996, Reuther et al. 2000). Each survey usually started at a bridge (if present at the site) and the maximum distance of $600 \mathrm{~m}$ was searched for the spraints (excrements) and clear tracks of otters (Lenton et al. 1980). If no otter signs were detectable, the site was considered "negative". At the majority of sites, as soon as otter signs were detected, the site was classified as "positive" and further search was omitted. In all cases at least $200 \mathrm{~m}$ of river banks were surveyed to evaluate the characteristics of the site.

At each site type of aquatic habitat and availability of food resources were described according to national monitoring scheme (Romanowski et al. 2015). Data on the trophy and richness of fish species of lakes and rivers surveyed were obtained from Operat ochrony zasobów... (1999).

\section{RESULTS AND DISCUSSION}

Signs of otters were found in $42(71.2 \%)$ sites located throughout the whole area of Wigry National Park. Otters inhabited aquatic habitats located as well in strict reserves in the Park, as in agricultural and developed areas. This result corresponds well with earlier data on otter occurrence and habitat selection in central and eastern Poland (Romanowski 2006). The percentage of positive sites was very high $(100 \%)$ in mesotrophic and eutrophic lakes as well as in rivers and meliorated canals (Table 1).

Table 1. Occurence of otter signs in aquatic habitats in Wigry National Park

\begin{tabular}{lccc}
\hline \multicolumn{1}{c}{ Habitat type } & Number of study sites & Number of positive sites & $\begin{array}{c}\text { Percentage of positive } \\
\text { sites }\end{array}$ \\
\hline Dystrophic lake & 17 & 0 & 0 \\
\hline Mesotrophic lake & 15 & 15 & 100 \\
\hline Eutrophic lake & 8 & 8 & 100 \\
\hline Other lakes & 8 & 8 & 100 \\
\hline River & 8 & 8 & 100 \\
\hline Drainage ditch & 3 & 3 & 100 \\
\hline Total & 59 & 42 & 71,2 \\
\hline
\end{tabular}

Dystrophic lakes located in the centre of peat-bogs (locally called "suchary") were the only habitat where no signs of otter presence were recorded. This marked difference in otter occurrence can be explained in the terms of different food availability. The main prey of otters consist of fish, supplemented with amphibians and crayfish (Brzeziński et al. 2006; Jędrzejewska et al. 2001). The otter is a species in whose diet fish constitute a large share 
(Macdonald 1990). Aquatic habitats of Wigry National Park are inhabited by 31 species of fish and 2 species of crayfish (Operat ochrony zasobów... 1999). The highest fish species richness was recorded in mesotrophic and eutrophic lakes (up to 28 species) and rivers (up to 18 species, Table 2 ).

Table 2. Characteristics of aquatic habitats surveyed for the presence of otters in Wigry National Park

\begin{tabular}{|c|c|c|c|c|}
\hline No. & Name & Habitat type & $\begin{array}{c}\text { Number of fish } \\
\text { species }\end{array}$ & Inventory result \\
\hline 1 & Białe Pierciańskie & mesotrophic lake & 12 & positive \\
\hline 2 & Białe Wigierskie & mesotrophic lake & 19 & positive \\
\hline 3 & Błotniste & lake & unknown & positive \\
\hline 4 & Czarne near Gawrych Ruda & mesotrophic lake & unknown & positive \\
\hline 5 & Czarne near Bryzgiel & mesotrophic lake & 7 & positive \\
\hline 6 & Długie Wigierskie & eutrophic lake & 18 & positive \\
\hline 7 & Gałęziste & lake & 9 & positive \\
\hline 8 & Klonek & mesotrophic lake & 7 & positive \\
\hline 9 & Konopniak & dystrophic lake & 1 & negative \\
\hline 10 & Królówek & eutrophic lake & 14 & positive \\
\hline 11 & Krusznik & mesotrophic lake & 12 & positive \\
\hline 12 & Leszczewek & eutrophic lake & 11 & positive \\
\hline 13 & Mulaczysko & mesotrophic lake & 12 & positive \\
\hline 14 & Muliczne & eutrophic lake & 16 & positive \\
\hline 15 & Okrągłe & eutrophic lake & 9 & positive \\
\hline 16 & Omułówek & eutrophic lake & 10 & positive \\
\hline 17 & Pierty & eutrophic lake & 18 & positive \\
\hline 18 & Pietronajcie & dystrophic lake & 2 & negative \\
\hline 19 & Postaw & mesotrophic lake & 10 & positive \\
\hline 20 & Przetaczek & lake & 5 & positive \\
\hline 21 & Samle Duże & lake & 9 & positive \\
\hline 22 & Samle Małe & lake & 9 & positive \\
\hline 23 & Suchar Dembowskich & dystrophic lake & 2 & negative \\
\hline 24 & Suchar I & dystrophic lake & 1 & negative \\
\hline 25 & Suchar II & dystrophic lake & 4 & negative \\
\hline 26 & Suchar III & dystrophic lake & 1 & negative \\
\hline 27 & Suchar IV & dystrophic lake & 2 & negative \\
\hline 28 & Suchar Rzepiskowy & dystrophic lake & 1 & negative \\
\hline 29 & Suchar V & dystrophic lake & 1 & negative \\
\hline 30 & Suchar VI & dystrophic lake & no fish & negative \\
\hline 31 & Suchar VII & dystrophic lake & 1 & negative \\
\hline 32 & Suchar Wielki & dystrophic lake & 5 & negative \\
\hline 33 & Suchar Wschodni & dystrophic lake & 2 & negative \\
\hline 34 & Suchar Zachodni & dystrophic lake & no fish & negative \\
\hline 35 & Sucharek near Bryzgiel & dystrophic lake & 2 & negative \\
\hline 36 & Ślepe (Krzyżańskie) & mesotrophic lake & no fish & positive \\
\hline 37 & Ślepe (Zielone) & dystrophic lake & no fish & negative \\
\hline 38 & Wądołek & dystrophic lake & 1 & negative \\
\hline 39 & Widne & eutrophic lake & 6 & positive \\
\hline 40 & Wigry & mesotrophic lake & 28 & positive \\
\hline 41 & Wygorzele & dystrophic lake & no fish & negative \\
\hline 42 & Czarna Hańcza & river & 17 & positive \\
\hline 43 & Gremzdówka & river & no fish & positive \\
\hline 44 & Kamionka & river & 18 & positive \\
\hline 45 & Maniówka & river & 9 & positive \\
\hline 46 & Piertanka & river & 9 & positive \\
\hline 47 & Wiatrołuża & river & 9 & positive \\
\hline
\end{tabular}

Data on number of fish species after Operat ochrony zasobów... (1999). 
In contrast, dystrophic lakes in the area are inhabited by low numbers of fish representing maximum five species (Operat ochrony zasobów... 1999). Their water contains high amount of humic acids - organic substances created during the decomposition of the foliage and soil rinsed from the surrounding coniferous forests. Therefore the water in the dystrophic lakes is acidic or slightly acidic. The majority of dystrophic lakes in the Wigry National Park are characterized by the presence of the anaerobic zone starting at the $2.5 \mathrm{~m}$ depth and containing hydrogen sulfide (Operat ochrony zasobów... 2014). These water characteristics result in low number and species composition of fish and therefore are not permanently colonised by otter. Consequently, in order to demonstrate the potential infrequent appearance of the otter in this type of water reservoirs, it is necessary to use different inventory methods, such as thermal imaging cameras and photo-traps.

Otter presence on the examined drainage ditches indicates that they function as migration corridors for the species in the park area. All drainage ditches were created in the period preceding the creation of the park. Currently their total length in the Wigry National Park is $19.5 \mathrm{~km}$ (Operat ochrony zasobów... 2014), with the average width of about $0.5 \mathrm{~m}$. They are usually not considered as optimal food sources and therefore are settled by otters only after saturation of optimal habitats, i.e. in conditions of high population size (Romanowski et al. 2013).

\section{CONCLUSIONS}

The mutual conditions between the various components of the Wigry National Park lake ecosystems are variable in time and space (Operat ochrony zasobów... 1999). The main reason for this variability is the succession of lakes resulting from eutrophication. In the case of the Wigry National Park, the species diversity and abundance of fish decide on the area settlement by the otter. Therefore, all rivers and lakes, excluding dystrophic ones, are inhabited by otter. This species penetrates evenly the waters banks, regardless of the degree of anthropopressure of the studied area. Despite the fact that the banks cover with tree vegetation and forest cover are high for all rivers and lakes, including distrophic lakes, these are not the parameters of the habitat condition that are evenly affecting the presence of otters. In the case of non-draining dystrophic lakes, it is surrounded by high-growing forest covering these lakes from the wind, shading their surface and directly acidifying water. In general, in most dystrophic lakes of the Wigry National Park, hydrochemical habitat conditions favour the maintenance of the disharmonicism of the analysed group of aquatic ecosystems, which affects the small species diversity of fish as the basic otters food. For this reason, dystrophic lakes are the only water reservoirs in the Wigry National Park not inhabited by otters.

\section{REFERENCES}

Brzeziński M., Romanowski J., Cygan J.P., Pabin B. 1996. Otter Lutra lutra distribution in Poland. Acta Theriol. 41, 113-126.

Brzeziński M., Romanowski J., Kopczyński Ł., Kurowicka E. 2006. Habitat and seasonal variations in diet of otters, Lutra lutra in eastern Poland. Folia Zool. 55, 337-348. 
Jędrzejewska B., Sidorovich V.E., Pikulik M.M., Jędrzejewski W. 2001. Feeding habits of the otter and American mink in Białowieża Primeval Forest (Poland) compared to other Eurasian populations. Ecography 24, 165-180.

Kranz A., Polednik L., Pinter V., Parz-Gollner R. 2001. Distribution, status and conservation of otters in Lower Austria. Wiss. Mitt. Niederösterr Landesmuseum 14, 39-50.

Lenton E.J., Chanin P.R.F., Jefferies D.J. 1980. Otter survey of England 1977-1979. London, Nature Conservancy Council.

Macdonald S.M. 1990. Surveys, in: Otters; an action plan for their conservation. Eds. P. Foster-Turley, S. Macdonald, C. Mason. Gland, IU CN Species Survival Commission, 8-10.

Macdonald S.M., Mason C.F. 1988. Observations on an otter population in decline. Acta Theriol. 33, 415-434.

Macdonald S.M., Mason C.F. 1994. Status and conservation needs of the otter (Lutra lutra) in the western Palaearctic. Nature Environ. 67, 1-54.

Mason C.F. 1989. Water pollution and otter distribution: a review. Lutra 32, 97-131.

Mason C.F., Macdonald S.M. 2004. Growth in Otter (Lutra lutra) populations in the UK as shown in long-term monitoring. Ambio 33, 148-152.

Operat ochrony zasobów i różnorodności gatunkowej ryb i raków w Wigierskim Parku Narodowym. Część 2. 1999. Report. Red. B. Zdanowski. [in Polish]

Operat ochrony zasobów i ekosystemów wodnych. Plan ochrony dla Wigierskiego Parku Narodowego i Obszaru Natura 2000 Ostoja Wigierska PLH 200004. 2014. Report. Red. A.S. Górniak. [in Polish]

Prigioni C., Balestrieri A., Remonti L. 2007. Decline and recovery in otter Lutra lutra populations in Italy. Mammal. Rev. 37, 71-79.

Reuther C., Dolch D., Green R., Jahrl J., Jefferies D. J., Krekemeyer A., Kucerova M., Madsen A.B., Romanowski J., Roche K., Ruiz-Olmo J., Teubner J., Trindade A. 2000. Surveying and Monitoring Distribution and Population Trends of the Eurasian Otter (Lutra lutra). Guidelines and Evaluation of the Standard Method for Surveys as recommended by the European section of the IU CN/SS C Otter Specialist Group. Habitat, Hankensbuttel 12, 1-152.

Romanowski J., Brzeziński M., Cygan J. 1996. Otter (Lutra lutra) distribution in Poland. Acta Theriol. 41, 113-126. [in Polish]

Romanowski J. 2006. Monitoring of the otter recolonisation of Poland. Hystrix It. J. Mammal. (n.s.) 17, 37-46.

Romanowski J., Brzeziński M., Żmihorski M. 2013. Habitat correlates of the Eurasian otter Lutra lutra recolonizing Central Poland. Acta Theriol. 58, 149-155.

Romanowski J., Zając T., Kozyra K. 2015. Wydra, w: Monitoring gatunków zwierząt. Przewodnik metodyczny. Część IV. Red. M. Makomaska-Juchiewicz, M. Bąk. Warszawa, GIOŚ, 388-424. [in Polish]

\section{WYSTĘPOWANIE WYDRY LUTRA LUTRA W ŚRODOWISKACH WODNYCH O RÓŻNEJ TROFII W WIGIERSKIM PARKU NARODOWYM}

Streszczenie. W pierwszych badaniach terenowych wydry euroazjatyckiej Lutra lutra, prowadzonych w Wigierskim Parku Narodowym (WPN) w północnej Polsce, zastosowano metodę standardową we wszystkich siedliskach wodnych. Łącznie 59 miejsc badań (48 jezior, 8 rzek i 3 rowy odwadniające) było odwiedzanych dwa razy między 12 a 18 marca oraz między 8 a 13 maja 2018 r. Ślady bytowania wydry stwierdzono w 42 (71,2\%) miejscach na terenie Wigierskiego Parku Narodowego. Odsetek miejsc z pozytywnymi stwierdzeniami osiągnął $100 \%$ w jeziorach mezotroficznych i eutroficznych, a także w rzekach i kanałach melioracyjnych. W jeziorach dystroficznych położonych w centrum torfowisk nie stwierdzono oznak obecności 
wydry. Tak znaczną różnicę w występowaniu wydry można wytłumaczyć różną dostępnością pokarmów - wysoką w siedliskach mezotroficznych i eutroficznych, niską w jeziorach dystroficznych.

Słowa kluczowe: monitoring przyrody, inwentaryzacja wydry, Wigierski Park Narodowy.

The research was financed from a forestry fund as part of a research project financed by the General Directorate of State Forests in Warsaw. 